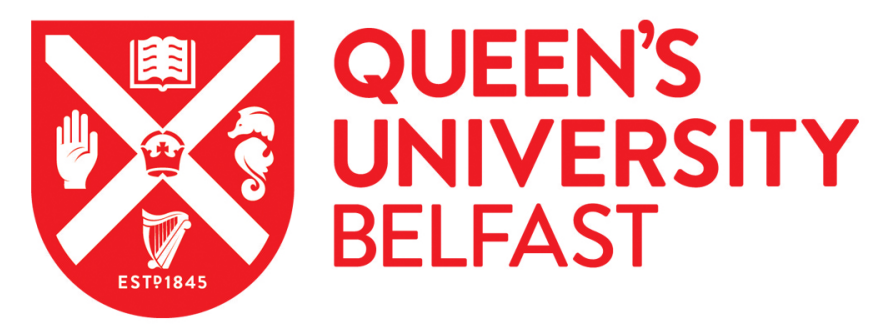

\title{
MO-FG-BRA-06: Material Optimisation for Nanoparticle-Sensitized Radiotherapy
}

McMahon, S., Paganetti, H., \& Prise, K. (2015). MO-FG-BRA-06: Material Optimisation for NanoparticleSensitized Radiotherapy. Medical Physics, 42(6), [3565]. https://doi.org/10.1118/1.4925410

\section{Published in:}

Medical Physics

\section{Document Version:}

Peer reviewed version

Queen's University Belfast - Research Portal:

Link to publication record in Queen's University Belfast Research Portal

Publisher rights

Copyright 2015 American Association of Physicists in Medicine.

\section{General rights}

Copyright for the publications made accessible via the Queen's University Belfast Research Portal is retained by the author(s) and / or other copyright owners and it is a condition of accessing these publications that users recognise and abide by the legal requirements associated with these rights.

Take down policy

The Research Portal is Queen's institutional repository that provides access to Queen's research output. Every effort has been made to ensure that content in the Research Portal does not infringe any person's rights, or applicable UK laws. If you discover content in the Research Portal that you believe breaches copyright or violates any law, please contact openaccess@qub.ac.uk. 
Material Optimisation for Nanoparticle-Sensitized Radiotherapy

S McMahon ${ }^{1}, \mathrm{H}$ Paganetti $^{1}$ and K Prise $^{2}$

${ }^{1}$ Massachusetts General Hospital, Boston, MA

${ }^{2}$ Queen's University Belfast, Belfast, UK

\section{Abstract}

Purpose:

To evaluate the potential applications of nanoparticles of different elemental compositions as X-ray radiosensitizers.

Methods:

Geant4 Monte Carlo models were used to model the interactions of $10 \mathrm{~nm}$ radius nanoparticles of elements ranging from silicon to mercury with either monoenergetic keV X-rays or a $6 \mathrm{MV}$ Linac spectrum Secondary electron spectra emitted from nanoparticles and resulting radial doses were calculated. Potential biological impacts were evaluated through the use of the Local Effect Model.

Results:

For keV radiation, fluoresence photons and energetic photoelectrons deposit the majority of energy emitted by nanoparticles, over long ranges. However, short-range energy deposition is dominated by Auger electrons. While total energy deposition increases with atomic number, short-range energy deposition has a more complex behaviour, with local maxima around germanium $(Z=32)$ and gadolinium ( $Z=64)$. For megavoltage radiation, Compton electrons deposit the majority of energy, but short- range depositions are dominated by interactions with secondary electrons. As a Result, energy deposition following ionising events following Linac irradiation is largely independent of atomic number.When analysed through the Local Effect Model, these effects translate into significant variations in predicted cell killing with atomic number for keV exposures, but comparatively limited effects for megavoltage exposures. Conclusions:

Although heavier elements typically lead to greater increases in dose within target volumes, on the nanometre scale effects are typically dominated by low-energy secondary electrons, whose distribution has a complex relationship with both nanoparticle composition and beam energy.These results suggest that maximum radiosensitization may not necessarily be achieved through maximizing atomic number, bu rather a balance between overall interaction cross-section and local dose distribution. The different behaviours seen when comparing keV and MV behaviours may also provide future mechanisms for separating physical and biological mechanisms of nanoparticle sensitisation, a key step in their development as a potential therapeutic agent. 
